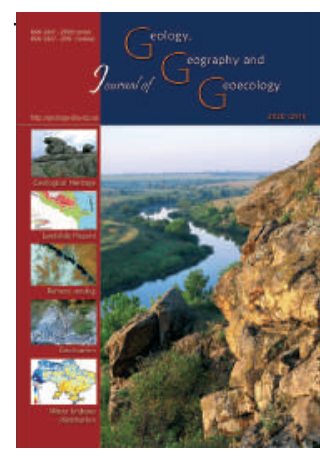

Journal of Geology. Geography and Geoecology

Journal home page: geology-dnu-dp.ua
ISSN 2617-2909 (print)

ISSN 2617-2119 (online)

Journ.Geol.Geograph.

Geology,

29(2), 327-334.

doi: $10.15421 / 112029$

Yuriy O. Kyselov

Journ. Geol. Geograph. Geoecology, 29(2), 327-334.

\title{
Geosophy as a scientific discipline: issues of methodology and metatheory
}

\author{
Yuriy O. Kyselov \\ Uman national university of horticulture,Uman, Ukraine, kyseljov@ukr.net
}

Received: 04.11.2019

Received in revised form: 25.11 .2020

Accepted: 27.02.2020

is geosophy, which originated about a hundred years ago at is human space, that is, space perceived and conceived by man. For a hundred years, this scientific discipline has undergone a difficult path of development, due to both internal, expressed in the nature of the discipline itself, and external (ideological, geopolitical, etc.) factors. Nowadays, post-non-classical methodological approaches are becoming more widely used in geosophy - besides geosophical, it is noospheric, synergistic, eco-evolutionary and passionate. They are based on a fundamentally new relationship between the subject and the research object, qualitatively different from what has traditionally been recognized as classical and non-classical geography. One feature of post-non-classical approaches is subject-object convergence. In particular, the content of the geophysical approach is to consider geographical features as totals that represent the interpenetrating unity of the mineral, organic and human components. Possibilities of its application exist in almost all sections of geography. A special place among the theoretical and methodological foundations of science is metatheoretical provisions - scientific developments that substantially go beyond this science. An essential feature of metatheory as an important attribute of science is its integrating role, both internally (enhancing systemic links between particular branches of science) and external (establishing and strengthening interdisciplinary links between the sciences of one cycle). Formation of metatheory involves the use of theoretical foundations, methods, approaches, evidence of other sciences, which has a verifiable, reflective, integrative and ideological significance. One of the main ones in all geography is the category of landscape. The ambiguity of its interpretation attests to the fundamental importance of this concept, its exceptional role in the knowledge of the Earth's surface as a multidimensional reality. From the diversity of landscape understandings, two basic concepts stand out. The content of one of them, dating back to the $19^{\text {th }}$ century, is to see the landscape as a general picture of the terrain, which from the point of view is interpreted as totality. From other positions, designed in the early twentieth century, the landscape is understood as a real existing natural material object, characterized by genetic homogeneity, the presence of vertical and horizontal structure and clearly defined boundaries. The coexistence of the aforementioned landscape concepts and the search for possibilities of combining them is one of the important theoretical problems of modern geography, in particular, geosophy.

Key words: geosophy, post-non-classical approaches, methodology, metatheory, landscape

\section{Геософія як наукова дисципліна: проблеми методології та метатеорії}

\author{
Ю. О. Кисельов
}

\section{Уманський національний університет садівництва, Умань, Україна, kyseljov@ukr.net}

Анотація. Наголошено на деяких теоретичних положеннях і метатеоретичних аспектах сучасної геософії, які доводять науковий характер цієї дисципліни, визначають iï місце у структурі географічного знання та методологічний рівень у контексті розвитку науки в цілому. Обгрунтувано належність геософічної думки та сформованого нею геософічного підходу в географічних дослідженнях до сфери постнекласики. Виділено положення геософії, що можуть становити складову метатеорії географії та окреслити геософічне значення ландшафту як загальногеографічного (а не лише природничо-географічного) дослідницького об'єкта. Зауважено, що зміст геософічного підходу полягає в розгляді географічних об'єктів як тотальностей, що являють собою взаємопроникну єдність мінеральної, органічної та антропічної складових. Можливості застосування цього підходу, який дозволяє пізнати не лише зовнішні ознаки досліджуваних об'єктів, а і їхню глибинну сутність, існують практично в усіх галузях природничої та суспільної географії. Наголошено на особливій ролі метатеоретичних положень науки - тих напрацювань, що змістовно виходять поза межі даної науки. Підкреслено, що суттєвою рисою метатеорії як важливого атрибуту науки є ii різнобічна інтегруюча роль. Формування метатеорії, потреба в якій зумовлена необхідністю розв'язання деяких 
методологічних проблем, передбачає використання атрибутів інших наук, що має верифікаційне, рефлексійне, інтегративне та світоглядне значення. Відзначено, що геософічний зміст має категорія ландшафту, що є однією з основних у географії. Зміст однієї з ландшафтознавчих концепцій, започаткованої у XIX ст., полягає в розумінні ландшафту як загальної картини місцевості. За іншою концепцією, розробленою на початку XX ст., ландшафт трактується як реально існуючий природний матеріальний об'єкт, що характеризується генетичною однорідністю, наявністю вертикальної й горизонтальної структури та має чітко окреслені межі. Неоднозначність трактування ландшафту засвідчує фундаментальне значення цього поняття, його виняткову роль у пізнанні земної поверхні як багатовимірної реальності. Прояви взаємопроникнення природного та людського компонентів свідчать про глибоку інтеграцію людини в ландшафт, що є підставою говорити про суб'єкт-об'єктну збіжність людини та ландшафту.

Ключові слова: геософія, постнекласичні підходи, методологія, метатеорія, ландшафт

Introduction. Geosophy is a relatively young science that emerged about a hundred years ago at the boundary of geography and philosophy, and has a human space as its object - a space that is perceived and conceived by a man. For a century, geosophy has undergone a complex and contradictory way of development, conditioned both by an internal factor expressed in the nature of the discipline itself (for it is a question of the boundaries of science and philosophy as specific spheres of human cognitive activity) and by external factors (ideological, geopolitical, etc.

In particular, at the initial stage (the 1920-1930ies) the content of geosophysical works there was mainly directed to philosophy, namely - irrationalism school, which was a manifestation of a common trend of a human thought of the period between two World wars. Bright representatives of that time geosophy were Ewald Banse (Banse, 1924) and Petr Savitsky (Savitski, 1997). After World War II, a remarkable event was John Kirtland Wright's publication, dedicated to the history of geographic ideas that had a geosophysical content (Wright, 1947).

It should be noted that a number of studies conducted during the XX - early XXI century and defined by their authors (who did not use the name «geosophy») as geocultural, historical and geographical, civilizational, etc. were in fact geosophical by their content. In particular, these were publications of Oswald Spengler (Spengler, 1921 - 1927), Arnold Toynbee (Toynbee, 1974), Yi-Fu Tuan (Yi-Fu Tuan, 1977), Thomas Barnes (Barnes, 1995), David Harvey (Harvey, 2006), Lev Gumilev (Gumilev, 2006), Henry Lefebvre (Lefebvre, 2007) and others, where a key topic was the issue of place and space in lives of human communities that inhabit them, and in particular the issue of landscape impact on shaping their spirituality, mentality and lifestyle.

After the decline of geosophy in the second half of the XX century with the emerge of a new global reality after the collapse of the world socialist system. As a natural result, a fundamental work of Andrzej Piskozub "Between Historiosophy and Geosophy" (Piskozub, 1994) was published immediately after decommunization of Poland. It should be noted that, compared to most geosophysical studies of the first half of the XX century, Andrzej Piskozub's research has a distinctly scientific character, since it has a cross-cutting evidence base of author's statements, clearly outlined analytical and synthetic components, and substantiated conclusions.

At the beginning of the XXI century, significant results in the field of geosophy were achieved by Oleh Shabliy (Shabliy, 2001), who outlined the essence and the main stages of the evolution of geosophysical constructs and characterized the main geosophysical topics of Ukraine since the times of the Ancient Kyivan state. Later the author of this article conducted his further geosophysical research in the aspects of development of theoretical and methodological foundations of geosophy, determination of its relations with other sciences and differentiation of human space of all Oecumene, and especially within Ukraine (Kyselov, 2011).

In parallel, from the end of the XX century, other directions of geosophy were developing. Thus, Volodymyr Derhachov associates geosophic constructions with the development of geographical aspects of sociomarginalism (Derhachov, 1998), and of openly subjective nature, like tendentious geopolitics of Karl Haushofer (Haushofer, 1934). They acquire nature of geosophical constructs, in particular in the context of analysis of geosophy's history, in publications of an ideologist of Russian imperialism Aleksandr Dugin (Dugin, 2017).

We consider it necessary to emphasize some theoretical positions and metatheoretical aspects of modern geosophy, which, in fact, confirm its scientific character, indicate the place of this discipline in the structure of geographical knowledge and determine its methodological level within the context of science development as a whole. In particular, below we attempt to substantiate the relation of geosophic concept and a geosophic approach articulated in geographic research to post-non-classics area, to identify those positions of geosophy that may be a part of the metatheory of geography, and to outline the geosophical importance of landscape as a general geographic (and not only natural and geographic) object of research. 
Geosophic Approach as a Post-Non-classics Phenomenon in Geography. At the beginning of the XXI century post-non-classical methodological approaches, including noospheric, synergetic, eco-evolutionary and passionate, are becoming more widely used in geographical studies. The above mentioned scientific approaches are based on a fundamentally new in history of science correlation between an object and a subject of study, qualitatively different from what was traditionally typical for classical and nonclassical geography. It is in the context of post-nonclassics that the subject and the object are combined into one inseparable whole.

The content of a geosophic approach is to consider geographical objects as totalities that represent the interpenetrating unity of the mineral, organic and human components. We can see the possibilities of its application in almost all branches of natural and social geography.

In particular, in landscape studies geosophic approach can be applied in interpretation of landscape as not only a hierarchically organized geosystem characterized by the genetic unity of components and the presence of structural components, but also as a medium of origin and habitat of an ethnic group and a factor of its mental and behavioral models. Depending on the zonal-sectoral type of landscape, the differences are expressed in worldview, culture, language, religion, and traditions. In particular, Western European peoples, created under the conditions of a moderately warm and humid Atlantic climate, possess liberal ideological values, along developed secular culture, a soft and melodic sound of language, breakaway in everyday life from religious tenets, etc. The majority of ethnicities of South-West and Central Asia, on the contrary, which emerged in a tropical and desert or high mountainous landscape are characterized by traditionalist worldview, asceticism, hard-spoken language, deep-set religion, and other traits that are typical for life in harsh conditions.

A clear example of geosophical approach application in population geography is a search for relationship between a climate and a type of population reproduction. In particular, nowadays there is an expanded natural population growth in countries that are confined to warm and very warm climates (unlike the Boreal and Sub-Boreal countries, where natural population growth is normal or negative). On the one hand, this fact requires a comprehensive analysis, which would take into account the particular nature of the use of certain regions of the world, ethnic and confessional composition of the population, socioeconomic factors. At the same time, the combined effect of these factors forms the sacral sphere of the respective region, which, being a holistic spiritual phenomenon, directly influences the peculiarities of the reproductive behavior of population.

Another demonstration of a geosophical approach is a study of migrations in the context of accessibility of an administrative center or agglomeration core in relation to periphery, as well as its remoteness from the geographical center of a region. The inconsistency of the actual localization of the core to the ideal central place may be due to historical, geographical or state-administrative factors. The need to overcome this situation, which does not meet the needs of today, necessitates the search for an optimal model of administrative and territorial structure, in which the centers of administrative and territorial units would be located as close as possible to their geographical centers. In this way, the main provisions of the theory of central places of Walter Cristaller would find their practical implementation. We consider the geosophic nature of this example in a holistic understanding of the totality of geospatial relationships and the factors of their formation, where a man - the subject of migration processes stands out.

In the field of economic geography, the example of using a geosophic approach is its elaboration from the perspective of reindustrialization of old industrial regions of the resource type. The discontinuation of traditional industries for industrial age naturally raises questions about the introduction of new ones based on modern technologies. We believe that the geosophic approach is manifested in the way how this new production is chosen, which in the newest conditions has little to do with once determining factors natural resource and proximity to the consumer - but essentially more - with the human factor (especially in the aspect of highly skilled labor resources).

In the field of social geography, the geosophic approach can be used, in particular, in studies of a geocultural sphere. It is a study of the spatial boundaries of geocultural regions, distinguished by such anthropospheric criteria as ethnic, linguistic, religious, mental community, which, as we noted above, is a landscape factor.

Political geography provides bright examples of the geosophic approach application. Political (in particular, electoral) preferences of the population often have a sufficiently deep rooting in the traits of its mentality, the degree of a national consciousness of individual sub-ethnoses, the historical features of development of their populated regions. In some cases, it is possible to draw parallels between current electoral-geographical barriers and historical borders 
and boundaries. Therefore, in our opinion, the issue of insufficient political and cultural consolidation of the Ukrainian nation can be solved precisely by using the geosophic approach.

Role of Geosophy in Formation of Metatheory of Geography. A versatile and multifaceted integration of science is the significant feature nowadays. In fact, in each of the modern fundamental sciences, the implementation of theoretical research is connected with the use of methodological apparatus, methods, concepts and terms of other sciences. Such interdisciplinary links eliminate the sharp barriers between the subject areas of related disciplines. Thus, the theory which is developed using different attributes of other science can acquire metatheoretical features. As professor Oleh Shabliy indicates, "each science has a number of theoretical problems that cannot be solved with the help of its internal conceptual categorical apparatus... Such problems are called metatheoretical" (Shabliy, 2001).

As geography is on the verge of the natural and social science cycles and has many different objects in common with other fields of knowledge, it is not only desirable, but even necessary, to reach the metatheoretical level. Relevant problems are inherent in both natural and social geography at the present stage of their development.

Among the theoretical and methodological foundations of science, metatheoretical provisions those scientific achievements that are substantially beyond this science, are of particular importance. An essential feature of metatheory as an important attribute of science is its integrating role, both internally (enhancing systemic links between particular branches of science) and external (establishing and strengthening interdisciplinary links between the sciences of one cycle). Formation of metatheory, the need for which is due to the need to solve some methodological problems, involves the use of theoretical foundations, methods, approaches, evidence of other sciences, which has a verification (verification of scientific theory by the provisions of another theory), reflective (self-determination by a given discipline of its place in science), integrative (establishing the closer links between sections of science), ideological (penetration into the essence of the object under study) value.

A significant contribution to the formation of metatheory of geography was made by Volodymyr Pashchenko, who identified 17 "relations that compose the specific substantive content of metatheoretical naturaland geographical generalizations" (Pashchenko, 2000). They include, in particular, "the targeted expansion and enrichment of worldview and philosophical foundations of natural geography” (Pashchenko, 2000, 38), “... specification and development of methodological grounds of research ..." (Pashchenko, 2000, 38), "generalization, correlation, correction and development through scientific reflection and interdisciplinary integration of the theory of each natural and geographical science, in particular, and common theoretical positions of natural geography in general" (Pashchenko, 2000, 39). In our opinion, these and other components of the content are fully consistent with the theoretical and methodological foundations of social geography and are constructive in the context of constructing its metatheory.

The need for geography in all-round communication with philosophy is indisputable. Their result was the development of a related discipline - geosophy. One of directions of introduction of its provisions in different geographical sciences is the development of a special geosophic approach to the study of terrestrial reality.

We believe that addressing metatheoretical problems of geography is closely related to its application of post-non-classical research approaches. Their essence particularly lies in the use of geography elements of theory, evidence or methods of other sciences, in particular, noosphere, synergetics, ecology, ethnology. With the help of each of the aforementioned sciences, geography, by expanding the range of its research objects is able to verify the correct formulation of its own theoretical positions. In particular, by drawing on the doctrine of the noosphere as a human-transformed biosphere into the research arsenal, geography formulates a new (more precisely, re-created) object - Oecumene, which, in our opinion, covers the entire surface of the Earth along with the nearest outer space. Therefore, the question arises about the relationship of concepts that denote certain conceptual interpretations of the Earth's surface - "geographical environment", "geospace", "Oecumene", "human space" and so on. The mentioned terminological problem is of a great theoretical and methodological significance, because it is a spatial object that "accommodates" the noosphere, a kind of "shell" of the last one.

Using a synergistic approach, Earth sciences view the objects they study as totalities, formed by the joint action of all factors involved in their genesis. New concepts may emerge to denote the processes associated with the unidirectional influence of different origin and force properties. As an example, the concept of "geostat" (Pashchenko, 1999) defined by Volody- 
myr Pashchenko or the concept of "geographical process" grounded by Oleksandr Kovalyov (Kovalyov, 1997), which reveal a significant variety of aspects of the existence and functioning of the Earth's landscape shell.

By applying the eco-evolutionary approach (the concept of "sustainable" or "supported", "balanced" development) and taking it as the paradigm of modern nature science, as suggested by Volodymyr Pashchenko mentioned above, modern geography involves provisions of the modern ecology in its theoretical and methodological foundations. The geography of this concept lies in laying its scientific foundations for ensuring the sustainability of landscapes in the conditions of increasing anthropogenic load on them.

Application of a passionate approach in geography provides its linkage to ethnology. In particular, the theory of passionarity formulated by Lev Gumilev points to the geographical content of the phenomenon of ethnicity, closely related to the landscape that "surrounds" it. The aforementioned author himself was convinced of the geographical nature of his theory (Gumilev, 2006).

We believe that along with the aforementioned, there is a geosophical approach the idea of which is to use theoretical and methodological foundations of geosophy in geographical studies. The application of this approach allows to know not only the external features of the studied objects, their internal structure, functioning and origin, but also their deep essence, which is to understand the importance of landscapes and entire countries (ethnic and national territories) for the nations which serve as environment of their lives. An example is a geosophical comprehension of the boundary character of a forest and steppe landscape - the arena of ethnogenesis of Ukrainians - in the context of the sub-ethnic diversity of this people, which is manifested in some features of their mentality, stereotypes of behavior, peculiarities of culture, etc. From the geosophical point of view, one of the key factors in the formation of these differences is landscape, since the basic morphological features of a territory (the general nature of the terrain, its abundance in water grid, the background type of soil, etc.) are determined to a large extent by certain mental, behavioral and activity-related (originally national occupations of people) ethnic and sub-ethnic characteristics of population.

We are convinced that the geosophic interpretation of objects' substance on the Earth's surface does not replace, but supplements, specific scientific, factual knowledge about them. Therefore, the verification role of the geosophic approach to results of geo- graphical studies becomes even more meaningful. Based on the dualistic nature of scientific knowledge (interpreted by modern philosophy and methodology as a synthesis of "logic" and "sophic" components (Epstein, 2004), we argue that the most consistent is the knowledge, the reliability of which is confirmed when carrying out research on a materialistic methodological basis (a specific "positive" science is framed in "logic" disciplines), as well as in the idealistic basis ("sophic" disciplines).

An example of involving a geosophic approach to the study of natural objects and phenomena is the development of the idea of "similar" and "opposite" landscapes. We see the concepts of "similar landscapes" close to the "zones-analogues" of Fedor Milkov (Milkov, 1970), but, unlike this scientist, the basis of their allocation is not the balance of moisture, but the morphological similarity, which is of a geosophic importance. That is, we consider "similar" not only the steppes of the temperate zone and the sub-equatorial savannas, but also the subarctic tundra. In addition, we find "similar" landscapes also within a single physical and geographical zone and even the natural zone - for example, the broad-leaved landscapes of the Atlantic and monsoon sectors of Eurasia.

With respect to "opposite" landscapes, in the context of the entire surface of the Earth, we distinguish "completely opposite" landscapes, which are land and water landscapes (aqualands of oceans and seas). In turn, we distinguish "relatively opposite" landscapes of different order within the continents. The first order "relative opposites" are plains and mountains; the second order - forested and forestless natural areas; third order - lowlands and highlands, taiga and deciduous forests and more.

We see the geographic content of the examples above in the sense that they have the character and spatial relationship of landscapes to the consciousness and existence of human communities, in particular ethnic groups.

In socio-geographical studies, a clear example of application the geosophical approach is given by political geography. The electoral preferences of the population are directly related to the historical features of the development of certain territories, and indirectly to natural factors (in particular, landscape and natural resources). A clear example of this thesis is given by Ukraine, which for many years has been fairly clearly divided electorally and geographically into the northwest and southeast. It is worth noting that this electoral and geographical boundary coincides with the southeastern border of the Old Ukrainian state in its 
significant connotation (hence, there is a link between political and geographical phenomena with historical and geographical ones). The elucidation of the deep essence of such a coincidence and the justification of the spatially expressed regularity are the part of the geosophical problem that arises in the context of the social geographic research. This problem can only be solved by using a geosophical approach.

Geosophical Interpretation of Landscape Category. One of the main categories in the whole geography is the landscape category. The ambiguity of its interpretation only attests to the fundamental importance of this concept, its exclusive role in the knowledge of the Earth's surface as a multidimensional reality. The geographical resources indicate (Hrodzynskyi, 2005; Kovalyov, 2009) that there are two basic concepts that stand out from the diversity of landscape understandings. The ideas of one such a concept were introduced in the 19 th century by Heinrich Hommeyer and Joseph Wimmer, is to see the landscape as a general picture of the terrain. From another perspective, originating from Lev Berg, the landscape is interpreted as a truly existing natural material object, characterized by genetic homogeneity, vertical and horizontal structure and clearly defined boundaries. In our view, the coexistence of the aforementioned landscape concepts and the search for the possibilities of their combination is one of the important theoretical (and metatheoretical, since the concept of the "landscape" is also "native" in art) problems of the modern geography, in particular geosophy.

We believe that the problem outlined is of particular importance at today's stage of knowledge evolution, marked by the ever-increasing role of synthesis - the union of the natural and human, material and spiritual, real and ideal, and so on. As we noted above, the development of geosophy in the 20-21 th centuries is one of the manifestations of this synthesis. Geosophical concepts, as well as a number of other new trends in geography, post-non-classical concepts, the emergence of which is cause by the ecological and, more broadly, anthropological-humanitarian crisis, imply the rejection of landscape only as an arena of industrial relations, which was typical for traditional Soviet landscape science. Aesthetic, ethno-cultural, sacral and other dimensions of being and nature of landscape are of increasing importance of the modern society. At the same time, objectively its integral components were and remain material components. Relief is one of the leading components of landscape. It has not only an influence on peculiarities of structure of other components but also it has a geosophical significance. In particular, Ch.-L. Montesquieu and
J.-G. Herder even in the $18^{\text {th }}$ century made an accent on the role of relief in forming the national character.

In recent decades, geographers along with studying the structure, functioning, origin and development of landscape as a material object have been actively exploring various aspects of its spirituality. According to Georg Wilhelm Hegel, the spirit is an absolute idea able to develop and define infinite being. Therefore, we are convinced that the study of spiritual foundations of landscape being is essential to knowing the full diversity of geographical features in the context of creating spatial images of the Earth's surface.

The opposite content of the spiritual and material mega-components of landscape is gnoseologically expressed in the formation and development of two of its basic aforementioned concepts - the classical one, which began in the early nineteenth century and is now being revived on a post-nonclassical methodological basis, and non-classical, expressed, in particular, in traditional Soviet landscape studies, represented by the works of Lev Berg, Leontii Ramensky, Nickolai Solntsev, Vladimir Sukachov, and others. The main features of this area are the recognition of the landscape reality, the presence of a vertical and horizontal structure in it, not including the number of human components. Instead, the followers of Heinrich Hommeyer and Joseph Wimmer in the Western world recognized the subjective characteristics of landscape in addition to the objective. From the late1980s, the viewpoint on the landscape as a subjectively created construct began to extend gradually also in the Soviet, and subsequently in the post-Soviet space (Armand, 1988).

The idea of the subjective and spiritual nature of landscape is closely linked to the recognition of a man as its component (that is, a man is not only the subject of knowledge but also of the landscape formation). We believe that the natural components of the landscape form only its "body", while the anthropic component represents its "soul". Since "body" and "soul" are opposites (thesis and antithesis), then, according to one of the main laws of dialectics - the law of unity and the struggle of opposites, they form a synthesis that is the spirit of the landscape, which, like material components, constantly develops and integrates the features of all its components (first of all, natural and anthropic mega-components). Due to the spirit, the landscape becomes the embodiment of Hegel's "absolute idea" in its continuous development.

In addition to the spirit category described above, we also apply the concept of consciousness towards understanding of landscape. Under consciousness of the landscape, we imply a thought developed in it as 
an absolute spirit, which is an immanent manifestation of Higher Powers in it, and a man as his material and spiritual thinking substance. The consciousness of landscape in this case is a synthesis of Divine idea and human thought. Thus, it means the aspect of landscape as a certain horizontal (territorial) fragment of the noosphere (in its Teilhard's interpretation). Both human and spirit are integral components of landscape. Therefore, we are convinced that a thought is not brought to landscape from the outside, but is created inside. Therefore, the consciousness of landscape, which is expressed in all the variety of thoughts and ideas, is its immanent property (Kyselov, 2010).

While the consciousness of landscape is, at least partially - is a matter of rational knowledge (since human thought has a very specific meaning), the spirit is an irrational phenomenon, which is predominantly sensory and, to a lesser extent, meaningful. This makes manifestations of the irrational in consciousness possible, since subjective consciousness naturally counteracts objective being. At the same time, the spirit of landscape, which is a synthesis of the natural and human in it, lends itself although incompletely enough to the rational knowledge.

In our opinion, the consciousness of the landscape determines its information field, which can be understood as consciousness in space. Therefore, the information field is a synthesis of consciousness and space. Visible manifestations of it in material geocomponents are relict elements that preserve memory of the landscape's past. Retrospective information also contains relatively ancient monuments of the human soul (archeological artifacts, ethnographic elements in architecture, etc.), which are factors in forming the spirit of the landscape. At the same time, newly formed landforms or newly constructed buildings represent progressive (which only indicates a possible direction for further development and does not have any qualitative value) elements of landscape and, accordingly, contain some predictive information on its evolution in the future.

By recognition a man as landscape's component, we take into account, above all, an ethnically selfaware human community. It is precisely for the ethnic group, as Petr Savitsky argued, that landscape acts as a "place of development", and in our opinion the ethnic group itself is the subject of a human "beingin-space". As a consequence of the landscape-ethnic interaction, the spirit of the earthly space is formed, which we regard as a more general concept, standing above the spirit of the landscape. In this case, the inherent natural features of the landscape (i.e., morphology reflected by ethnic consciousness) predetermine the spiritual traits of the ethnos, which, in turn, enhances the spiritual sphere of landscape (i.e., the "soul" interacts with the "body"). So, as we noted above, this spirit, co-creating with a rational anthropospheric attribute - a human thought, forms the consciousness of the earthly space. The last one, herewith, acquires the traits inherent in the noospheric stage of the development of a "humanized" landscape.

Elements of geographical determinism, expressed in the recognition of the determinative landscape character of the spirituality of ethnic groups, was proclaimed by the founder of Ukrainian national scientific geography Stepan Rudnytsky, who in particular noted: "Islam is a faith that grew up in the sandy and rocky decent of etesian wind strip of our globe. It spreads across deserts and blooms magnificently there. When it [faith] gets out of the desert, it is difficult for it to nest" (Rudnytskyi, 1994).

Conclusions. The provided examples of interpenetration of the natural and human to the deep integration of a man into the landscape, which is the reason to speak about the subject-object convergence of a man (initially - subject) and landscape (object). This is a clear sign of the belonging of the geosophical approach to post-non-classical methodological elaborations.

We have defined geosophical approach in constructing the metatheory of geography, as well as outlined possibilities of its application in various fields, which give grounds to conclude about its endto-end character as a certain element of the system of geographical disciplines. The geosophical approach plays a verifiable, reflective and integrative role in geographical studies, and reinforces the worldview and philosophical foundations for the whole geography.

One of the components of the intangible sphere of the landscape is its spirit and consciousness. In addition, the spirit is its substance, combining the sensory aspects of landscape perception, while consciousness is an expression of the rational foundations of its being, focusing on both Divine idea and human thought, specifically (spatially) expressed in ethnic mentality. Due to the latter last one, it a scientific knowledge of various manifestations of landscape consciousness becomes possible.

An attempt to explain a number of important scientific and philosophical categories related to the concept of the "landscape", testifies to the fundamental possibility of combining in it the spiritual and material foundations of its being, caused by the embodiment of the idea and self-knowing thought. We have outlined a triad of concepts that in their synthesis 
(made in relation to landscape) make the categories of "spirit", "consciousness", "information field". Those categories conceptually combine spiritual and material, ideal and real, subjective and objective components in organic whole, expressing the synthetic nature of the essence of landscape as a spatial phenomenon. The above mentioned dialectical relations can rule as the epistemological basis in the further development basing on the geophysical interpretation of landscape of its synthetic and material-spiritual concept.

\section{References}

Armand, A. D., 1988. Landshaft kak konstruktsiya [Landscape as a construction] Izvestiya Vsesoyuznogo Geograficheskogo obshchestva [Bulletin of the All-Union Geographical society], vol. 120, 2, 120-125 (in Russian).

Banse, E., 1924. Die Seele der Geographie. Geschichte einer Entwicklung [The soul of geography. History of a development]. Georg Westermann, Braunschweig (in German).

Barnes, T., 1995. Logics of dislocation: Models, Metaphors, and Meanings of Economics Space. The Guilford Press.

Derhachov, V. O., 1998. Raskalennyie rubezhi: ocherki marginalnoy kommunikativnosti [Affair boundaries: essays of marginal communicability]. Astroprynt, Odesa (in Russian).

Dugin, A. G., 2017. Noomakhiya: geosofiya: gorizonty i tsivilizatsiyi [Noomachia: geosophy: horizonts and civilizations]. Moscow (in Russian).

Epstein, M. N., 2004. Znak probela. O budushchem gumanitarnykh nauk [The sign of gap. About the future of human natures]. Novoye literaturnoye obozreniye, Moscow (in Russian).

Gumilev L. N., 2006. Etnogenez i biosfera Zemli [Ethnogenesis and the biosphere of the Earth]. AirisPress, Moscow (in Russian).

Harvey, D., 2006. Spaces of global capitalism: towards a theory of uneven geographical development. London: Verso.

Haushofer, K., 1934. Weltpolitik von heute [World politics from today]. Zeitgeschichte-Verlag Wilhelm Andermann, Berlin (in German).

Hrodzynskyi, M. D., 2005. Piznannia landshaftu: mistse i prostir: U 2 tomakh [Cognition of the landscape: place and space: In 2 volums]. Kyiv (in Ukrainian).

Kovalyov, O. P., 1997. Heohrafichnyi protses: shcho stoiit za tsym ponyattyam? [Geographical process: what stays behind this notion?] Ukrayinskyi heohrafichnyi zhurnal [Ukrainian geographical journal], 20 (4), 45-51 (in Ukrainian).

Kovalyov, O. P., 2009. Landshaft sam po sebe i dlya cheloveka [Landscape as own-by-self and for man]. Burun-knyha, Kharkiv (in Russian).

Kyselov, Yu. O., 2010. Do problemy heosofichnoyi kontseptsii landshaftu [To the issue of a geosophical conception of landscape] Fizychna heohrafiia ta heomorfolohiia [Physical geography and geomorphology], 61 (4), 6-10 (in Ukrainian).

Kyselov, Yu. O., 2011. Osnovy heosofii: problemy teorii ta metodolohii [Fundamentals of geosophy: issues of theory and methodology]. Luhansk Taras Shevchenko national university, Luhansk (in Ukrainian).

Lefebvre, H., 2007. Production of space. Blackwell, Oxford.

Milkov, F. N., 1970. Landshaftnaya sfera Zemli [The landscape sphere of the Earth]. Mysl, Moscow (in Russian).

Pashchenko, V. M., 1999. Metodolohiia postneklasychnoho landshaftoznavstva [Methodology of the post-non-classic landscape science]. Kyiv (in Ukrainian).

Pashchenko V. M., 2000. Zemleznannya: Knyha 1. Metodolohiia pryrodnycho-heohrafichnykh nauk [Land knowledge: Book 1. Methodology of natural and geographical sciences]. Kyiv (in Ukrainian).

Piskozub, A., 1994. Mędzy historiozofią a geozofią [Between historiosophy and geosophy]. Gdańsk (in Polish).

Rudnytskyi, S. L., 1994. Do osnov ukraiinskoho natsionalizmu [To the fundamentals of the Ukrainian nationalism] Chomu my khochemo samostiinoii Ukraiiny? [Why we want independent Ukraine?]. Svit, Lviv, 271-348 (in Ukrainian).

Savitski, P. N., 1997. Kontinent Yevraziia [The continent of Eurasia]. Agraf, Moscow (in Russian).

Shabliy, O. I., 2001. Suspilna heohrafiia: teoriia, istoriia, ukraiinoznavchi studii [Human geography: theory, history. Ukrainian studies]. Lviv Ivan Franko national university, Lviv (in Ukrainian).

Spengler, O., 1921-1927. Untergang des Abendlandes: In 2 Bänden [Decline of the West: in 2 volums]. C.H. Beck'sche Verlagsbuchhandlung, München (in German).

Toynbee, A. J., 1974. A Study of History ( $4^{\text {th }}$ ed.). Dell Publishing Co., Inc., New York.

Tuan, Yi-Fu., 1977. Space and place: the Perspective of Experience. Univ. of Minnesota Press, Minneapolis.

Wright, J. K., 1947. Terrae Incognitae: The Place of Imagination in Geography. Annals of the Association of American Geographers, vol. 37, 1-15. 